\title{
Year-long deployments of small geolocators increase corticosterone levels in murres
}

\author{
Kyle H. Elliott ${ }^{1, *}$, Laura McFarlane-Tranquilla ${ }^{2}$, Chantelle M. Burke ${ }^{2}$, April Hedd ${ }^{2}$, \\ William A. Montevecchi ${ }^{2}$, W. Gary Anderson ${ }^{1}$ \\ ${ }^{1}$ Department of Biological Sciences, University of Manitoba, Winnipeg, Manitoba R3T 2N2, Canada \\ ${ }^{2}$ Cognitive and Behavioural Ecology Program, Memorial University of Newfoundland, St. John's, Newfoundland A1B 3X9, \\ Canada
}

\begin{abstract}
Geolocators provide information on the year-round movements of birds. The effect of the year-round deployment of such devices has, however, largely been examined via measures that are relatively insensitive to small changes in nutritional condition, such as return body mass, return rate and reproductive success. To address this issue, we equipped 34 common murres Uria aalge and 35 thick-billed murres $U$. lomvia at 6 colonies in the eastern Canadian Arctic and subArctic with geolocators for $1 \mathrm{yr}$ and measured baseline corticosterone levels (4 colonies) and body mass (6 colonies) upon device retrieval. Across all colonies, birds equipped with geolocators averaged higher levels of corticosterone and lower body mass than controls, although there were substantial differences among colonies. Despite effects of the devices on corticosterone and body mass, survival $(90 \%)$ in equipped birds was no different than in control birds at the one colony where long-term resighting data were available, and chick feeding rates were also similar between equipped and unequipped birds. We suggest that even very small devices can cause chronic stress when applied over long periods, at least for a diving bird with a very high wing loading, but effects on birds in the present study were not sufficiently pronounced to influence adult survival or chick provisioning rates.
\end{abstract}

KEY WORDS: Device effects - Geolocators . Common murre · Uria aalge · Thick-billed murre . Uria lomvia

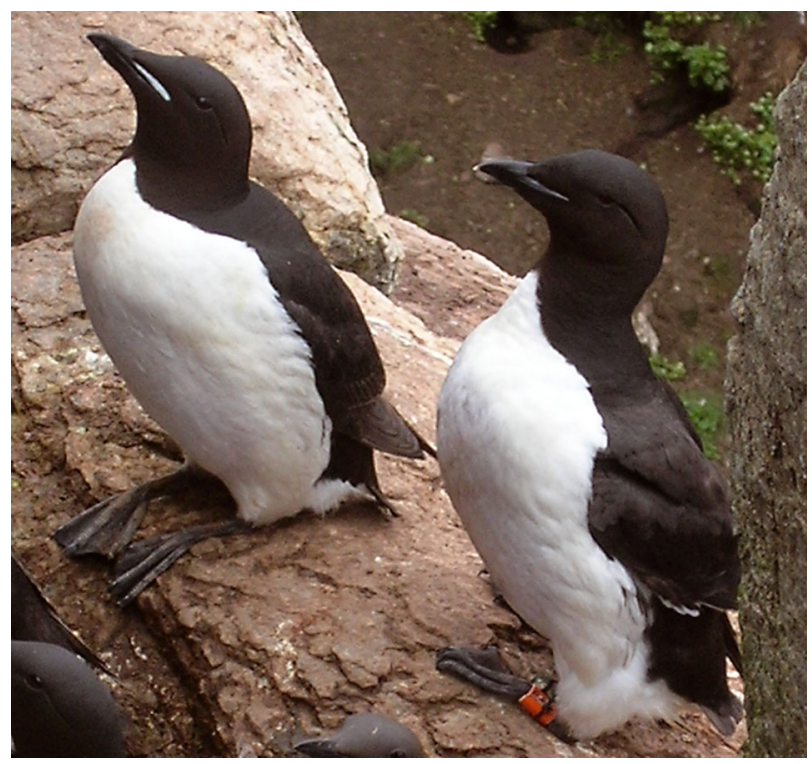

A thick-billed murre with a geolocator (red band) weighing $0.5 \%$ of body weight.

Photo: L. McFarlane-Tranquilla

\section{INTRODUCTION}

Geolocators are small electronic loggers that record light levels, thereby allowing biologists to estimate animal positions (Wilson et al. 1992, Hill 1994, Weimerskirch \& Wilson 2000, Phillips et al. 2004). Geolocators have provided data on the nonbreeding spatial distribution and migratory patterns of seabirds (Gaston et al. 2011, Hedd et al. 2011, Pinet et al. 2011) that were difficult to study without 
this technology. A major benefit of geolocators is their small size, which reduces the influence of the device on behaviour (Wilson 2001, Phillips et al. 2003, 2004, Ropert-Coudert \& Wilson 2005). Geolocators have therefore been deployed on small birds, including species for which implantation of satellite transmitters has been unsuccessful (Hatch et al. 2000, Stutchbury et al. 2009, Gaston et al. 2011).

Glucocorticoid hormones such as corticosterone, the main glucocorticoid in birds, are involved in the regulation of energy intake, storage and mobilization (Landys et al. 2006). During acute stress (for example, when chased by a predator), corticosterone levels increase and the birds enter an emergency life history stage. During this stage, the birds usually respond to higher corticosterone levels by mobilizing energy stores, increasing locomotory activity and inhibiting reproduction (Romero \& Wikelski 2010, Landys et al. 2006). In contrast, during chronic stress (for example, nutritional or social stress over days or weeks), corticosterone levels also increase, but to a much lesser degree, impairing cognition, immune status and survival while promoting behaviours that increase selfmaintenance (self-feeding) over reproduction (Brown et al. 2005, Kitaysky et al. 2007, Goutte et al. 2010, Romero \& Wikelski 2010). If an animal's ability to forage is impinged by an external device, the animal may become chronically stressed, and an increase in circulating, baseline corticosterone levels may be detectable (Suedkamp Wells et al. 2003, Tremblay et al. 2003, Takahashi et al. 2008, Pereira et al. 2009).

Attaching any type of logger to seabirds can affect their behaviour (Barron et al. 2010, Elliott et al. 2010b; reviewed by Phillips et al. 2003); geolocators, for example, increase drag when attached via a harness (Bowlin et al. 2010). Although geolocators weigh very little, auks are particularly susceptible to the effects of attachment because of their high flight costs (Hatch et al. 2000, Elliott et al. 2010b, Vandenabeele et al. 2012). The effects of long-term attachment of relatively large geolocators (compared to the bird's body size) have been assessed through calculations based on drag on frozen birds in a wind tunnel (Bowlin et al. 2010) and measurements of reduction in chick-provisioning rates (Adams et al. 2009, Carey et al. 2009). To determine whether small geolocators measurably affect birds, we obtained blood samples from common murres Uria aalge and thick-billed murres $U$. lomvia that had carried a geolocator weighing <5 $\mathrm{g}$ for $1 \mathrm{yr}$. Blood samples were then assayed for corticosterone levels within 3 min of capture, as a measure of chronic nutritional stress (Kitaysky et al. 2007, Doody et al. 2008).

\section{MATERIALS AND METHODS}

\section{Field methods}

Three types of geolocator (British Antarctic Survey) were deployed on breeding murres: the Mk 5 and 7 , weighing $3.6 \mathrm{~g}$ in air, and the Mk 13, weighing $1.8 \mathrm{~g}$ ( $~ 0.3$ to $0.5 \%$ of adult mass including $\sim 1 \mathrm{~g}$ of glue, cable tie and Darvic band). Each logger was attached to a Darvic band fastened around the tarsus (details in Gaston et al. 2011). Birds were caught by means of neck nooses. Geolocators were deployed from August 2007 to July 2008 at Coats Island, July 2007 to July 2008 at Funk Island, July 2008 to July 2009 at Gull Island, August 2008 to July 2009 at Digges Island, August 2008 to July and August 2009 at Prince Leopold Island and July 2008 to July 2009 at the Gannet Islands (Fig. 1). Control birds were captured at the same time as geolocators were retrieved from equipped birds at each site, and individuals from the 2 treatment groups were matched in terms of status (incubating or brooding) and cliff ledge where we captured them. Control and geolocator birds being equivalent was an important assumption within our study, as it is possible that we selected 'easier to catch' control birds that had better body condition. Nonetheless, at the Coats Island colony we recorded time-to-capture, and there was no difference between equipped and control birds (28 \pm 17 vs. $24 \pm 10 \mathrm{~s} ; t_{28}=0.61, \mathrm{p}=0.51$ ).

Birds were weighed with a Pesola scale, and except at Prince Leopold and Digges (due to logistic constraints at those field stites), were bled onto Whatman blood spot cards from the brachial vein within 3 min of recapture. The blood spot cards were airdried overnight, placed in individual plastic bags and kept at air temperature $\left(0\right.$ to $20^{\circ} \mathrm{C}$ in the Canadian Arctic) or refrigerated $\left(4^{\circ} \mathrm{C}\right)$ until assayed for corticosterone. The blood spot procedure has been successfully used for hormonal analysis in many studies (Worthman \& Stallings 1994, Shirtcliff et al. 2001, Fleming et al. 2002, Sanvito et al. 2004, Delahunty et al. 2007) and has been validated against serum for common murres (Doody et al. 2008). The greatest advantage of using blood spots instead of serum is that samples do not need to be frozen after sampling, thus providing a convenient way to store and transport samples during extended periods of field work where freezer access is limited. We also used the blood spot cards to determine the sex of the bird using PCR with sex-specific primers (Elliott et al. 2010a). In 2010, we recorded the chick-provisioning rate of 8 birds equipped with geolocators and their 


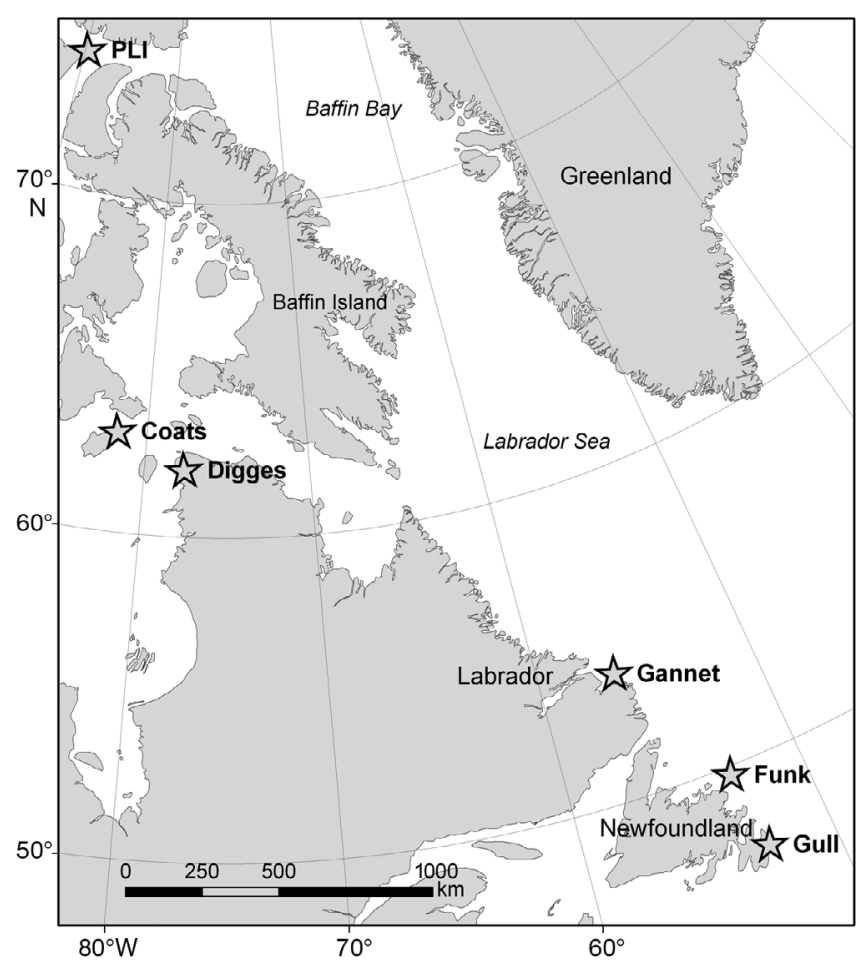

Fig. 1. Sampling sites of common murres Uria aalge (colonies at Funk, Gannet and Gull Islands) and thick-billed murres U. lomvia (colonies at Coats, Digges and Prince Leopold [PLI] Islands), Canada

partners at Coats Island (see Elliott et al. 2008 for methods). At Coats Island, where there is an intensively monitored colour-banded population, we also recorded survival of birds equipped in 2007 during the breeding season of 2008. Specifically, we examined both partners at all breeding sites surrounding those sites where geolocators were attached and spent dozens of hours at each of the sites trying to find potential non-breeding, equipped birds. We compared those data to survival data from colourbanded, unequipped birds at the same study site over the same winter. Because of our high resighting probabilities $(\sim 100 \%)$, we assumed that return rates were indicative of survival.

\section{Corticosterone radioimmunoassay}

Three holes (diameter: $3 \mathrm{~mm}$ ) were punched from the filter card blood samples into a $4 \mathrm{ml}$ test tube containing $200 \mu \mathrm{l}$ of radioimmunoassay (RIA) buffer (0.1 M phosphate buffer, $0.9 \% \mathrm{NaCl}[\mathrm{w} / \mathrm{v}]$, and $0.5 \%$ bovine serum albumin [w/v]). Each sample was vortexed to ensure complete dissolution and was kept refrigerated for $24 \mathrm{~h}$ to allow dissolution into the buffer. A standard curve was created by adding known concentrations ( 0.025 to $50 \mathrm{ng} \mathrm{ml}^{-1}$ ) of corticosterone standard (Steraloids) mixed in RIA buffer onto the filter cards. The cards were then dried at $4{ }^{\circ} \mathrm{C}$ for $1 \mathrm{mo}$, and standards were punched out into $4 \mathrm{ml}$ tubes containing $200 \mu \mathrm{l}$ of RIA buffer. We also diluted a series of plasma samples, dried them on the filter cards, and assayed the dried samples to examine parallelism of the standard curve. We included plasma samples from 10 murres with known corticosterone levels, as assayed on ethanol-extracted plasma using the same methodology. To each of the test tubes, we then added $100 \mu \mathrm{l}$ of tritiated (5000 disintegrations per minute) corticosterone (GE Healthcare, 78.1 MBq $\mathrm{mol}^{-1}$, Code TRK406) and $100 \mu \mathrm{l}$ of sheep serum anticorticosterone (diluted 1:50000; Antibodies-online, Code ABIN343319). After $1 \mathrm{~h}$ incubation at room temperature, samples were incubated at $4^{\circ} \mathrm{C}$ for a minimum of $18 \mathrm{~h}$. The reaction was stopped through the addition of $100 \mu \mathrm{l}$ of dextran $(0.5 \% \mathrm{w} / \mathrm{v})$-coated charcoal $(5 \% \mathrm{w} / \mathrm{v})$ to each assay tube. After $15 \mathrm{~min}$ on ice, assay tubes were centrifuged for $30 \mathrm{~min}$ at $4{ }^{\circ} \mathrm{C}$ $(2500 \times g)$, and the supernatant was decanted into $7 \mathrm{ml}$ scintillation vials. Finally, $4 \mathrm{ml}$ of scintillation fluid (Ultima Gold, Perkin Elmer) was added to each assay tube, and tubes were counted on a liquid scintillation counter (LS6500, Beckman Coulter) for $5 \mathrm{~min}$. All samples were counted in duplicate, and corticosterone concentration of each sample was interpolated from the standard curve that was counted in triplicate. Inter-assay and intra-assay coefficients of variation for corticosterone were 7.4 and $12.2 \%$, respectively, samples demonstrated good parallelism (ANCOVA, $\left.F_{3,20}=1.98, \mathrm{p}=0.15\right)$, and values from blood spot cards were highly correlated with values from plasma $\left(t_{9}=8.89, \mathrm{R}^{2}=0.92, \mathrm{p}<0.0001\right)$. The minimum detection level was $0.05 \mathrm{ng} \mathrm{ml}^{-1}$.

\section{Statistical analysis}

We log-transformed average corticosterone values for each individual murre to achieve normality, whereas we did not transform body mass as it was already normally distributed (Shapiro-Wilk test). We used body mass rather than scaled mass index or size-adjusted mass, because scaled mass index does not predict energy stores ('body condition') in seabirds, including murres, and size-adjusted mass does not substantially improve predictability in murres (Jacobs et al. 2012). For each parameter (mass and corticosterone), we constructed a general linear model 
Table 1. Uria aalge and $U$. lomvia. Mean $( \pm \mathrm{SD})$ body mass and corticosterone levels from whole blood samples of common and thick-billed murres from different colonies in northeastern Canada that had been equipped (Equ) with a geolocator for 1 yr or unequipped (control; Con). Geolocators weighed 3 to $5 \mathrm{~g}$ (0.3 to $0.5 \%$ of murre body mass); na: not available

\begin{tabular}{|c|c|c|c|c|c|c|c|c|c|c|c|c|c|c|}
\hline \multirow{3}{*}{$\begin{array}{l}\text { Species } \\
\text { Colony }\end{array}$} & \multicolumn{7}{|c|}{ - Body mass } & \multicolumn{7}{|c|}{ - Corticosterone } \\
\hline & \multicolumn{2}{|c|}{ Equipped } & \multicolumn{2}{|c|}{ Control } & \multirow[t]{2}{*}{$t$} & \multirow[t]{2}{*}{$\mathrm{df}$} & \multirow[t]{2}{*}{$\mathrm{p}$} & \multicolumn{2}{|c|}{ Equipped } & \multicolumn{2}{|c|}{ Control } & \multirow[t]{2}{*}{$t$} & \multirow[t]{2}{*}{$\mathrm{df}$} & \multirow[t]{2}{*}{$\mathrm{p}$} \\
\hline & (g) & $\mathrm{n}$ & (g) & $\mathrm{n}$ & & & & $\left(\mathrm{ng} \mathrm{ml}^{-1}\right)$ & $\mathrm{n}$ & $\left(\mathrm{ng} \mathrm{ml}^{-1}\right)$ & $\mathrm{n}$ & & & \\
\hline \multicolumn{15}{|l|}{ Common murre } \\
\hline Funk & $900 \pm 35$ & 8 & $924 \pm 35$ & 8 & 1.16 & 15 & 0.26 & $6.5 \pm 13.7$ & 13 & $1.9 \pm 6.5$ & 10 & 2.30 & 21 & 0.03 \\
\hline Gull & $960 \pm 56$ & 9 & $945 \pm 53$ & 9 & 0.11 & 15 & 0.92 & $13.2 \pm 8.4$ & 9 & $7.6 \pm 2.3$ & 10 & 2.16 & 17 & 0.05 \\
\hline Gannet & $926 \pm 70$ & 10 & $950 \pm 68$ & 10 & 0.39 & 18 & 0.89 & $3.3 \pm 6.4$ & 12 & $1.5 \pm 2.4$ & 16 & 2.21 & 26 & 0.04 \\
\hline \multicolumn{15}{|c|}{ Thick-billed murre } \\
\hline Coats & $1022 \pm 68$ & 14 & $1033 \pm 49$ & 9 & 0.77 & 21 & 0.29 & $4.3 \pm 4.4$ & 15 & $1.8 \pm 0.6$ & 15 & 6.82 & 22 & $<0.001$ \\
\hline Digges & $1061 \pm 38$ & 5 & $1028 \pm 55$ & 22 & 1.47 & 25 & 0.85 & na & na & na & na & na & na & na \\
\hline Prince Leopold & $883 \pm 61$ & 15 & $894 \pm 47$ & 8 & 0.45 & 21 & 0.66 & na & na & na & na & na & na & na \\
\hline
\end{tabular}

Table 2. Mean $\left( \pm \mathrm{SD}\right.$ ) corticosterone levels from whole blood samples $\left(\mathrm{ng} \mathrm{m} \mathrm{m}^{-1}\right.$ ) or fecal samples (ng $\mathrm{g}^{-1}$ ) of wild birds that had been equipped with a location device or unequipped (control). Note that different instrumentation was used in these studies than in the present study. For experiments with multiple sampling, we only collated data for the last date recorded. p-value are from $t$-tests

\begin{tabular}{|c|c|c|c|c|c|c|c|c|}
\hline \multirow{2}{*}{ Species } & \multirow{2}{*}{ Duration } & \multirow[t]{2}{*}{ Location } & \multicolumn{2}{|c|}{ _ Geolocator } & \multirow[t]{2}{*}{ Equipped } & \multirow{2}{*}{ Control } & \multirow[t]{2}{*}{$\mathrm{p}$} & \multirow[t]{2}{*}{ Source } \\
\hline & & & $\begin{array}{l}\text { Weight } \\
\text { (g) }\end{array}$ & $\begin{array}{l}\% \text { of body } \\
\text { mass }\end{array}$ & & & & \\
\hline Thick-billed murre & $2-4 \mathrm{~d}$ & Alaska & 17 & 2.5 & $6.5 \pm 3.8 \mathrm{ng} \mathrm{ml}^{-1}$ & $4.5 \pm 2.1 \mathrm{ng} \mathrm{ml}^{-1}$ & 0.81 & Takahashi et al. (2008) \\
\hline Common murre & $2-3 d$ & Norway & 27 & 3 & $6.3 \pm 6.0 \mathrm{ng} \mathrm{ml}^{-1}$ & $4.0 \pm 3.0 \mathrm{ng} \mathrm{ml}^{-1 \mathrm{a}}$ & 0.37 & Tremblay et al. (2003) \\
\hline American kestrel & $8 \mathrm{wk}$ & Brazil & $6^{\mathrm{b}}$ & $5^{\mathrm{b}}$ & $175 \pm 73 \mathrm{ng} \mathrm{g}^{-1}$ & $194 \pm 53 \mathrm{ng} \mathrm{g}^{-1}$ & 0.99 & Pereira et al. (2009) \\
\hline
\end{tabular}

with Sex, Colony and Treatment as covariates. We also used $t$-tests to examine the significance at each colony. We used a significance level of $\alpha=0.05$.

\section{RESULTS AND DISCUSSION}

In birds equipped with geolocators, corticosterone levels were twice as high as in controls, and body weight was lower at 4 of 6 colonies. Specifically, Colony $\left(F_{3,75}=6.58, \mathrm{p}=0.0006\right)$ and Treatment $\left(F_{1,75}=19.0, \mathrm{p}<0.0001\right)$, but not $\operatorname{Sex}\left(F_{1,75}=1.41, \mathrm{p}=\right.$ 0.24 ) or any interaction (all $\mathrm{p}>0.1$ ) significantly accounted for the variation in corticosterone levels. In contrast, Sex $\left(F_{1,116}=8.51, \mathrm{p}=0.0002\right)$, Colony $\left(F_{5,116}=25.9, \mathrm{p}<0.0001\right)$ and Treatment $\left(F_{1,116}=3.99\right.$, $\mathrm{p}=0.048$ ), but none of the interactions (all $\mathrm{p}>0.2$ ) significantly accounted for the variation in body mass. At 3 of the 4 colonies (all but Gull), the difference in corticosterone levels was statistically significant (Table 1). Corticosterone levels tended to decline with increasing body mass at all colonies, but the trend was never statistically significant (regression, $\mathrm{p}>0.05)$. We observed no clear signs of skin abrasion or direct physical damage at the site of attachment of the geolocators.

Corticosterone levels at 3 of our 4 colonies were about $50 \%$ lower than those found in other studies (Tremblay et al. 2003, Takahashi et al. 2008, our Tables 1 \& 2), but our values are not directly comparable to other methods as some of the corticosterone may not be bound by the filter paper. Murres at the fourth colony, Gull Island, had 3 to 4 times higher corticosterone levels than at the other 3 colonies. Our Gull Island samples were obtained early in the season, before the arrival of spawning capelin Mallotus villosus (Doody et al. 2008), potentially causing additional nutritional stress for the murres at this colony. The inter-colony variability in air temperature (and its possible linkage to corticosterone degradation) and environmental variation is one reason why we included colony as a factor in our statistical models.

In contrast to our study, 3 previous studies examining device effects on wild birds did not show any statistical difference between corticosterone levels of equipped and control birds, although 2 of the studies (both on murres) over short time-scales $(<4 \mathrm{~d})$ indicated a trend of higher levels of corticosterone in the 
equipped birds (Tables $1 \& 2$ ) . Other studies examining at-sea behaviour, return rates, body mass or chick provisioning rates over short time-scales suggested that leg-mounted devices, such as those used in this study, minimally affected dive behaviour (Elliott et al. 2007, 2008, Ropert-Coudert et al. 2009, Carey 2011). Perhaps the small effect of leg-mounted devices becomes measurable when compounded over an entire year. Previous studies have suggested a stronger effect of short-term compared to long-term attachment due to handling stress or device accommodation (Suedkamp Wells et al. 2003, Fallow et al. 2009); however, short-term deployments had no effect on corticosterone levels (Table 2), while our year-long deployments showed statistically significant effects (Table 1). We suggest that corticosterone is a better measure of device effect following longterm attachment applications. Long-term reductions in foraging success, as a result of the device attachment, may result in measurable and cumulative chronic stress. Short-term variation in corticosterone may be more closely associated with time-sincefeeding, masking any variation associated with device attachment.

At Coats Island, 17 of 20 equipped birds were resighted, all of which were breeding (observed with chicks or eggs), in the summer of 2008, and 1 other bird was resighted, also breeding, in 2009 (Gaston et al. 2011). This proportion (18 of 20) is identical to the survival rate $(90 \%)$ of non-equipped birds at Coats Island (K. H. Elliott \& A. J. Gaston unpubl. data). Similarly, the chick-provisioning rate of equipped birds $\left(\right.$ mean $\pm \mathrm{SD}: 3.62 \pm 2.34$ feeds $\mathrm{d}^{-1}$ ) was similar to the provisioning rate of non-equipped birds $(3.77 \pm 2.71$ feeds $\mathrm{d}^{-1}$, within-pair paired $t_{7}=0.72, \mathrm{p}=0.66$ ) at Coats Island. We have no similar data from other colonies (visits were short and recapture rates were likely unrepresentative of survival), but our results for Coats Island suggest that adults may have compensated for any decrease in foraging abilities to maintain chick growth rates. It is also possible that breeding partners compensated for potentially reduced parental investment of the tagged adult (Paredes et al. 2005). Overall it seems that device effects were surmountable and not so pronounced as to affect adult survival; however, corticosterone levels, which directly reflect nutritional stress (Kitaysky et al. 2007, Doody et al. 2008), are perhaps more sensitive measures than return rates, chick provisioning rates or body mass.

Elevated levels of corticosterone can increase mortality (Brown et al. 2005, Kitaysky et al. 2007, Goutte et al. 2010, Romero \& Wikelski 2010) or decrease mortality (Cote et al. 2006, Cabezas et al. 2007), indicating the existence of an optimal level of corticosterone for individual survival (Brown et al. 2005). We found an increase in corticosterone with no effect on murre survival at 1 colony (Coats Island), suggesting that the increased levels of corticosterone were not high enough to substantially reduce survival. In contrast, larger devices that presumably have a more pronounced effect on corticosterone levels affect resighting rates (Paredes et al. 2005). While the geolocators in our study were perhaps not large enough to cause a substantial decrease in survival, they did result in a 2- to 3-fold increase in corticosterone levels. An increase of that magnitude is known to reduce nest attendance in seabirds, and presumably increase self-feeding rates (Kitaysky et al. 2001).

Our results are supported by previous research on small birds. For example, return rates of small passerines were low after carrying geolocators (weighing 2.7 to $3.5 \%$ of body mass) year-round (Montevecchi et al. 2009, Stutchbury et al. 2009). Adams et al. (2009) tagged both members of sooty shearwater Puffinus griseus breeding pairs with geolocators weighing $1.4 \%$ of body mass and found that none of the offspring fledged at a mass necessary for postfledging survival, compared with $54 \%$ for pairs with only 1 member equipped and $83 \%$ for control pairs (Adams et al. 2009). Adult body mass of equipped birds was no different between capture and recapture 1 yr later in a separate study of sooty shearwaters (Hedd et al. 2012). Geolocators weighing 0.7 to $1 \%$ of body mass attached to short-tailed shearwaters Ardenna tenuirostris for $1 \mathrm{yr}$ had no statistically significant effect on adult body mass, and return rate was $74 \%$ for equipped birds compared with $82.5 \%$ for control birds (Carey et al. 2009). A more detailed study on short-tailed shearwaters found no effect of geolocators weighing 0.7 to $1 \%$ of body mass on adult body mass, chick body mass, hatching success or adult return rate either in the short term (1 to $10 \mathrm{wk}$ after device attachment) or the long term (1 yr after device attachment) (Carey 2011). There was no relationship between device mass and return rate across 8 species of petrels equipped with geolocators $<2 \%$ of body mass, although return rates were $<50 \%$ for 3 species (Carey et al. 2009).

Modelling suggests that birds with high wing loadings, such as murres, are more affected by devices than birds with low wing loadings, such as shearwaters (Vandenabeele et al. 2012), which may explain why our results were more pronounced than in studies such as that by Carey (2011). Flight ability coupled with migration distance may also explain some 
of the variation among colonies; all individuals from the same colony wintered largely in the same region, and birds at Coats migrated much farther (to the north Atlantic Gaston et al. 2011) than birds from the Gannet, Funk and Gull colonies (to offshore Newfoundland; Hedd et al. 2011). Overall, it seems that device effects were surmountable and not so pronounced as to affect adult survival or reproductive succes; however, corticosterone levels, which directly reflect nutritional stress (Kitaysky et al. 2007, Doody et al. 2008), are perhaps more sensitive measures than return rates, chick provisioning rates or body mass. In particular, although treatment had an overall significant effect on body mass, the effect size was much smaller than for corticosterone, and the effect was not significant at any one colony independently.

Acknowledgements. We are indebted to our many field assistants that managed to obtain excellent data often under unpleasant conditions, especially K. Elner, J. Provencher, P. Smith and K. Woo. A. J. Gaston organized the data collections in the High Arctic, and P. Regular helped at colonies in Newfoundland and Labrador. An International Polar Year Grant (principal investigators W.A.M. and A. J. Gaston) provided financial support for the field work, and an NSERC Discovery Grant awarded to W.G.A. provided financial support for the laboratory assays.

\section{LITERATURE CITED}

Adams J, Scott D, McKechnie S, Blackwell G, Shaffer SA, Moller H (2009) Effects of geolocation archival tags on reproduction and adult body mass of sooty shearwaters (Puffinus griseus). NZ J Zool 36:355-366

Barron DG, Brawn JD, Weatherhead PJ (2010) Meta-analysis of transmitter effects on avian behaviour and ecology. Methods Ecol Evol 1:180-187

Bowlin MS, Henningsson P, Muijres FT, Vleugels RHE, Liechti F, Hedenström A (2010) The effects of geolocator drag and weight on the flight ranges of small migrants. Methods Ecol Evol 1:398-402

> Brown CR, Brown MB, Raout SA, Smith LC, Wingfield JC (2005) Effects of endogenous steroid hormone levels on annual survival in cliff swallows. Ecology 86:1034-1046

> Cabezas S, Blas J, Marchant TA, Moreno S (2007) Physiological stress levels predict survival probabilities in wild rabbits. Horm Behav 51:313-320

Carey MJ (2011) Leg-mounted data-loggers do not affect the reproductive performance of short-tailed shearwaters (Puffinus tenuirostris). Wildl Res 38:740-746

Carey MJ, Meathrel CE, May NA (2009) A new method for the long-term attachment of data-loggers to shearwaters (Procellariidae). Emu 109:310-315

> Cote J, Clobert J, Meylan S, Fitze PS (2006) Experimental enhancement of corticosterone levels positively affects subsequent male survival. Horm Behav 49:320-327

$>$ Delahunty KM, McKay DW, Noseworthy DE, Storey AE (2007) Prolactin responses to infant cues in men and women: effects of parental experience and recent infant contact. Horm Behav 51:213-220

Doody LM, Wilhelm SI, McKay DW, Walsh CJ, Storey AE (2008) The effects of variable foraging conditions on common murre (Uria aalge) corticosterone concentrations and parental provisioning. Horm Behav 53:140-148

Elliott KH, Davoren GK, Gaston AJ (2007) The influence of buoyancy and drag on the dive behaviour of an arctic seabird, the thick-billed murre. Can J Zool 85:352-361

> Elliott KH, Woo K, Gaston AJ, Benvenuti S, Dall'Antonia L, Davoren GK (2008) Seabird foraging behaviour indicates prey type. Mar Ecol Prog Ser 354:289-303

> Elliott KH, Gaston AJ, Crump D (2010a) Sex-specific behaviour by a monomorphic seabird represents risk partitioning. Behav Ecol 21:1024-1032

- Elliott KH, Shoji A, Campbell KL, Gaston AJ (2010b) Oxygen stores and foraging behavior of two sympatric, planktivorous alcids. Aquat Biol 8:221-235

Fallow PM, Chiaradia A, Ropert-Coudert Y, Kato A, Reina RD (2009) Flipper bands modify the short-term diving behavior of little penguins. J Wildl Manag 73:1348-1354

Fleming AS, Corter C, Stallings J, Steiner M (2002) Testosterone and prolactin are associated with emotional responses to infant cries in new fathers. Horm Behav 42:399-413

> Gaston AJ, Smith PA, McFarlane-Tranquilla L, Montevecchi WA and others (2011) Movement and wintering areas of breeding age thick-billed murre Uria lomvia from two colonies in Nunavut, Canada. Mar Biol 158:1929-1941

Goutte A, Angelier F, Welcker J, Moe B and others (2010) Long-term survival effect of corticosterone manipulation in black-legged kittiwakes. Gen Comp Endocrinol 167: 246-251

Hatch SA, Meyers PM, Mulcahy DM, Douglas DC (2000) Performance of implantable satellite transmitters in diving seabirds. Waterbirds 23:84-94

> Hedd A, Montevecchi WA, McFarlane-Tranquilla L, Burke CM and others (2011) Reducing uncertainty on the Grand Bank: Tracking and vessel surveys indicate mortality risks for common murres in the North-West Atlantic. Anim Conserv 14:630-641

> Hedd A, Montevecchi WA, Otley H, Phillips RA, Fifield DA (2012) Trans-equatorial migration and habitat use by sooty shearwaters Puffinus griseus from the South Atlantic during the nonbreeding season. Mar Ecol Prog Ser 449: $277-290$

Hill RD (1994) Theory of geolocation by light levels. In: LeBoeuf BJ, Laws RM (eds) Elephant seals: population ecology, behavior, and physiology. University of California Press, Berkeley, CA, p 227-236

Jacobs SR, Elliott KH, Guigueno MF, Gaston AJ, Redman P, Speakman JR, Weber JM (2012) Determining seabird body condition using nonlethal measures. Physiol Biochem Zool 85:85-95

Kitaysky AS, Wingfield JC, Piatt JF (2001) Corticosterone facilitates begging and affects resource allocation in the black-legged kittiwake. Behav Ecol 12:619-625

Kitaysky AS, Piatt JF, Wingfield JC (2007) Stress hormones link food availability and population processes in seabirds. Mar Ecol Prog Ser 352:245-258

- Landys MM, Ramenofsky M, Wingfield JC (2006) Actions of glucocorticoids at a seasonal baseline as compared to stress-related levels in the regulation of periodic life processes. Gen Comp Endocrinol 148:132-149

Montevecchi WA, McFarlane-Tranquilla L, Buren A, Burke C and others (2009) Effects of geolocators in studies of 
avian movement ecology. Science E-letter, 23 April 2009. www.sciencemag.org/content/323/5916/896.short/reply \#sci_el_12186.

Paredes R, Jones IL, Boness DJ (2005) Reduced parental care, compensatory behaviour and reproductive costs of thick-billed murres equipped with data loggers. Anim Behav 69:197-208

Pereira RJG, Granzionolli MAM, De Barros FM, Duarte JMB (2009) Influence of radiotransmitters on fecal glucocorticoid levels of free-ranging male American kestrels. J Wildl Manag 73:772-778

Phillips RA, Xavier JC, Croxall JP (2003) Effects of satellite transmitters on albatrosses and petrels. Auk 120: 1082-1090

Phillips RA, Silk JRD, Croxall JP, Afanasyev V, Briggs DR (2004) Accuracy of geolocation estimates for flying seabirds. Mar Ecol Prog Ser 266:265-272

Pinet $\mathrm{P}$, Jaquemet S, Pinaud D, Weimerskirch H, Phillips RA, Le Corre M (2011) Migration, wintering distribution and habitat use of an endangered tropical seabird, Barau's petrel Pterodroma baraui. Mar Ecol Prog Ser 423:291-302

Romero LM, Wikelski M (2010) Stress physiology as a predictor of survival in Galapagos marine iguanas. Proc Biol Sci 277:3157-3162

Ropert-Coudert Y, Wilson RP (2005) Trends and perspectives in animal-attached remote sensing. Front Ecol Environ 3:437-444

Ropert-Coudert Y, Kato A, Poulin N, Grémillet D (2009) Legattached data loggers do not modify the diving performances of a foot-propelled seabird. J Zool (Lond) 279: 294-297

Sanvito S, Galimberti F, Delahunty KM, McKay DW (2004) Blood spots in Pinnipedia hormone studies: measure of cortisol levels in southern elephant seals (Mirounga Leonia). Aquat Mamm 30:251-256

Editorial responsibility: Rory Wilson, Swansea, UK
Shirtcliff EA, Reavis R, Overman WH, Granger DA (2001) Measurement of gonadal hormones in dried blood spots versus serum: verification of menstrual cycle phase. Horm Behav 39:258-266

Stutchbury BJM, Tarof SA, Done T, Gow E and others (2009) Tracking long-distance songbird migration by using geolocators. Science 323:896

Suedkamp Wells KM, Washburn BE, Millspaugh JJ, Ryan MR, Hubbard MW (2003) Effects of radio-transmitters on fecal glucocorticoid levels in captive dickcissels. Condor 105:805-810

Takahashi A, Matsumoto K, Hunt GL, Shultz MT and others (2008) Thick-billed murres use different diving behaviors in mixed and stratified waters. Deep-Sea Res II 55: 1837-1845

Tremblay Y, Cherel Y, Oremus M, Tveraa T, Chastel O (2003) Unconventional ventral attachment of time-depth recorders as a new method for investigating time budget and diving behaviour of seabirds. J Exp Biol 206: 1929-1940

Vandenabeele SP, Shepard EL, Grogan A, Wilson RP (2012) When three per cent may not be three per cent; deviceequipped seabirds experience variable flight constraints. Mar Biol 159:1-14

> Weimerskirch H, Wilson RP (2000) Oceanic respite for wandering albatrosses. Nature 406:955-956

Wilson RP (2001) Beyond rings on birds for determination of movements: wither the archival tag. Ardea 89:231-240

Wilson RP, Ducamp JJ, Rees G, Culik BM, Niekamp K (1992) Estimation of location: global coverage using light intensity. In: Priede IM, Swift JM (eds) Wildlife telemetry: remote monitoring and tracking of animals. Ellis Horwood, Chichester, p 131-134

Worthman CM, Stallings JF (1994) Measurement of gonadotropins in dried blood spots. Clin Chem 40:448-453

Submitted: March 2, 2012; Accepted: August 2, 2012 Proofs received from author(s): September 3, 2012 